Peters, J. P. \& Van Slyke, D. D. (1931). Quantitative Clinical Chemistry, vol. 2. London: Baillière, Tindall and Cox.

Pfaltz, M. H. \& Baudisch, O. (1923). J. Amer. chem. Soc. 45, 2972.

Rigg, T., Stein, G. \& Weiss, J. (1952). Proc. Roy. Soc. A, 211, 375.

Scholes, G., Stein, G. \& Weiss, J. (1949). Nature, Lond., 164, 709.

Scholes, G. \& Weiss, J. (1950). Nature, Lond., 166, 640.

Scholes, G. \& Weiss, J. (1951). Nature, Lond., 167, 693.

Sevag, M. G., Lackman, D. B. \& Smolens, J. (1938). J. biol. Chem. 124, 425.

Smith, D. B. \& Butler, G. C. (1951). J. Amer. chem. Soc. $731,2$.
Sparrow, A. H. \& Rosenfeld, F. M. (1946). Science, 104, 245.

Stein, G. \& Weiss, J. (1949). J. chem. Soc. p. 3245, 3256.

Stern, R. G., Brasch, A. \& Huber, W. (1949). Abstr. Amer. chem. Soc., 115th Meeting, Div. biol. Chem. 24 C.

Stone, W. E. (1943). J. biol. Chem. 149, 29.

Sullivan, M. X. (1935). Proc. Soc. exp. Biol., N.Y., 33, 166.

Taylor, B., Greenstein, J. P. \& Hollaender, A. (1948). Arch. Biochem. 16, 19.

Vischer, E. \& Chargaff, E. (1948). J. biol. Chem. 176, 715. Wegmüller, F. (1942). Ph.D. Thesis, Berne.

Weiss, J. (1944). Nature, Lond., 153, 748.

Weiss, J. (1947a). Trans. Faraday Soc. 43, 314.

Weiss, J. (1947 b). Brit. J. Radiol. (Suppl.), 1, 56.

\title{
Urinary Steroids
}

\section{FORMATION AND DETERMINATION OF 3:5-DINITROBENZOATES OF ALCOHOLIC STEROIDS}

\author{
By A. E. KELLIE, E. R. SMITH AND A. P. WADE \\ The Courtauld Institute of Biochemistry, Middlesex Hospital \\ Medical School, London, W. 1
}

(Received 26 May 1952)

Very few general methods have been suggested for the estimation of the non-ketonic alcohol fraction from urine. Dobriner, Lieberman \& Rhoads (1948) employed an electrometric titration method depending on the formation of half esters of the alcohols with phthalic anhydride and the titration of these with dilute alkali. In model experiments with pure compounds good results were obtained, but the method did not prove satisfactory when applied to urinary extracts. Tompsett \& Oastler (1948) weighed the half succinates of the neutral non-ketonic fraction of urinary extracts. The use of the antimony trichloride reaction (Pincus, 1943) has been suggested (Pincus, 1948), but no reports of its application have appeared.

Engel, Patterson, Wilson \& Schinkel (1950) described a colorimetric method for steroid alcohols which has been applied to clinical material. By analogy with the Zimmermann reaction a colour would be expected if a steroid complex containing the $m$-dinitrophenyl group was treated with alkali in the presence of excess of ketone. This group of workers tried the 3:5-dinitrobenzoates but found them very sparingly soluble in either aqueous or ethanolic potassium hydroxide. However, the hemi-3:5-dinitrophthalates obtained from primary and secondary alcohols were soluble in alkali, and on treatment with methanolic potassium hydroxide gave a red coloration in the absence of a ketone. No separation of individual alcohols was attempted.
The object of the present work was to prepare derivatives of the steroid alcohols which would lend themselves both to chromatographic separation and quantitative estimation.

Acetates and benzoates have already been employed in isolation studies. The former have been used for chromatographic separations but do not lend themselves to quantitative estimation; they can, however, be characterized in the finger-print region of the infrared spectrum $\left(1200-800 \mathrm{~cm}^{-1}\right)$ (Jones \& Dobriner, 1949). Benzoates have not been widely used for separating steroid alcohols, but recent work by Brooks, Klyne \& Miller (1951) has shown that many pairs of related benzoates can be separated by chromatography on alumina. By virtue of the phenyl radical such esters absorb in the ultraviolet region of the spectrum and could be detected and estimated.

The steroid alcohols can be esterified with 3:5dinitrobenzoyl chloride and the resulting esters, when treated with dilute alkali in the presence of a ketone, give an intense purple colour characteristic of the $m$-dinitrophenyl group. Colour development is complete within 5 min. and acetone will act both as the solvent medium and as the ketone required by the reaction. A method has been developed by studying the conditions for the production of maximum optical density, and has been used for the determination of dinitrobenzoyl esters. 
The successful application of this colour reaction rested mainly upon two essentials: (i) finding the conditions for complete esterification of the nonketonic alcohol fraction, and (ii) the chromatographic separation of the esters so formed.

\section{EXPERIMENTAL}

Method of esterification. A solution of the alcohol or nonketonic alcohol fraction of urine (containing about $10 \mathrm{mg}$.) is evaporated to dryness in a small tube. If ethanol has been used as solvent, all traces must be removed. This may be done by dissolving the residue in benzene and evaporating again to dryness. Freshly recrystallized 3:5-dinitrobenzoyl chloride (50 mg.) and pyridine $(0.1 \mathrm{ml}$.) are added, and the tube lightly stoppered and heated for 30 sec. in a boilingwater bath. The contents become homogeneous. The mixture is then quickly transferred with benzene $(25 \mathrm{ml}$.) to a separating funnel and washed successively with $\mathrm{N}-\mathrm{HCl}$ $(2 \times 10 \mathrm{ml}$.), $\mathrm{N}-\mathrm{NaOH}(5 \times 10 \mathrm{ml}$.) and water $(4 \times 10 \mathrm{ml}$. $)$. The benzene solution is dried over $\mathrm{Na}_{2} \mathrm{SO}_{4}$ and evaporated to dryness under reduced pressure. A blank esterification is made periodically to check reagents.

\section{Estimation of 3:5-dinitrobenzoates}

Reagents. Acetone (redistilled), ethanol and 0.1\% (w/v) $\mathrm{KOH}$ (A.R.) in ethanol.

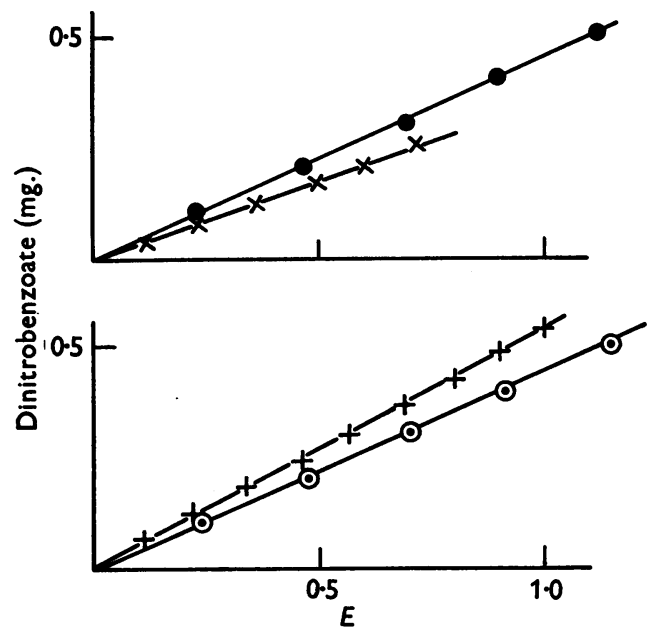

Fig. 1. Optical density $(E)$-weight relationships for steroid 3:5-dinitrobenzoates. $\bigcirc$, androsterone; $\odot-\odot$, androst-5-en-3 $\beta$-ol-17-one; $\times-\times$, pregnane-3 $\alpha$ :20 $\alpha$-diol; +-+ , cholesterol.

Procedure. The 3:5-dinitrobenzoyl ester containing approx. $0.08 \mathrm{mg}$. of dinitrobenzoyl radical is obtained dry in a test tube and dissolved, by warming when necessary, in $0.8 \mathrm{ml}$. acetone. The solution is cooled to room temperature and $0.2 \mathrm{ml}$. of $0.1 \% \mathrm{KOH}$ in ethanol added. After $5 \mathrm{~min}$. $9 \mathrm{ml}$. of ethanol (or acetone) are added and the optical density $(E)$ of the purple solution measured in a $1 \mathrm{~cm}$. cell with a Hilger Spekker absorptiometer using a yellow filter (Ilford 606).
Blank determinations carried out on the reagents in the absence of a dinitrobenzoyl ester give no colour $(E<0.01)$.

When, after esterification, more material than the equivalent of $0.08 \mathrm{mg}$. of dinitrobenzoyl radical is present, the product is dissolved in an appropriate volume of solvent and a portion containing approx. $0.08 \mathrm{mg}$. of dinitrobenzoyl radical is used to determine the optical density $(E)$ in a $1 \mathrm{~cm}$. cell. From this observation $(E)$ the total optical density equivalent of the solution is calculated as the product of the observed optical density and the dilution $(E \times d)$.

Calibration. Calibration curves drawn (Fig. 1) for the 3:5dinitrobenzoyl esters of cholesterol, androsterone, androst5 -en-3 $\beta$-ol-17-one, and pregnane-3 $\alpha: 20 \alpha$-diol over the range $0 \cdot 1-0.5 \mathrm{mg}$. show the proportionality between optical density and weight. Cholesterol 3:5-dinitrobenzoate (0.243 mg.) gave a mean optical density of 0.459 (five observations, range $0.455-0.462$, mean deviation $0.5 \%$ ).

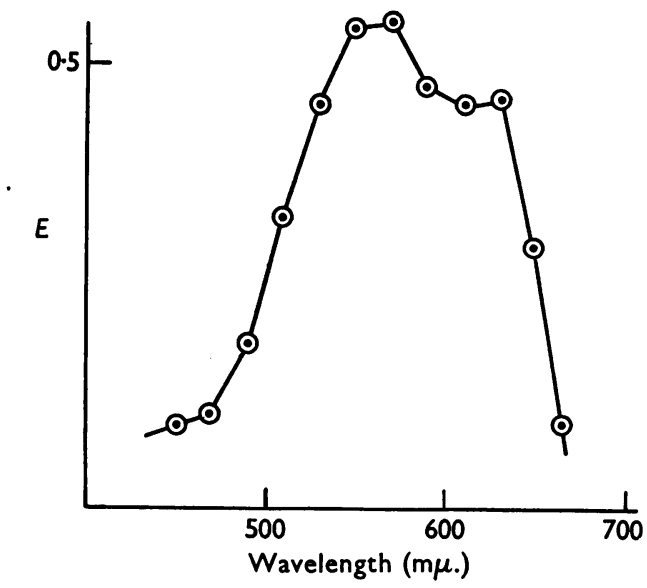

Fig. 2. Absorption spectrum given by $0.243 \mathrm{mg}$. of cholesterol 3:5-dinitrobenzoate in $10 \mathrm{ml}$. of acetone containing $0.2 \mathrm{mg}$. of $\mathrm{KOH}$. $1 \mathrm{~cm}$. cell. $E=$ optical density determined with Hilger Uvispek absorptiometer.

\section{Absorption spectrum}

Fig. 2 shows the absorption spectrum of the purple colour produced in this reaction by cholesterol ester. (The term 'ester' in this paper refers to 3:5-dinitrobenzoyl esters.) Similarly, androsterone and pregnanediol esters showed maximum absorption in the visible region at 550-570 $\mathrm{m} \mu$. (Ilford filter 606 has a maximum transmittance in this region) and some absorption in the red. The purple colour of the reaction changed to red within $3 \mathrm{hr}$. of diluting with ethanol. Cholesterol hemi-3:5-dinitrophthalate dissolved in acetone when treated with $0.1 \% \mathrm{KOH}$ in ethanol gave a purple colour similar to that given by the dinitrobenzoyl ester.

\section{Sensitivity of optical density to conditions of reaction}

Temperature of reaction. Table 1 shows the effect of carrying out the colour reaction on cholesterol 3:5-dinitrobenzoate at various temperatures. Optical density falls off slightly with increasing temperature of reaction, but variation with temperature is so slight that it is convenient to carry out the reaction at $15^{\circ}$. 
Table 1. Effect of temperature of reaction on optical density of colour produced by cholesterol 3:5dinitrobenzoate $(0.243 \mathrm{mg}$.) in ethanolic $\mathrm{KOH}$

$\begin{array}{cc}\text { Temp. of reaction } & \begin{array}{c}\text { Optical density }(E) \\ (1 \mathrm{~cm} . \text { cell })\end{array} \\ 5 & 0.464 \\ 11 & 0.460 \\ 15 & 0.457 \\ 20 & 0.450 \\ 25 & 0 \cdot 434 \\ 29 & 0.420\end{array}$

Time of reaction. Two esters, cholesterol ester and pregnanediol di-ester and a mixture of unknown esters (an esterified non-ketonic alcohol fraction from human urine), were treated in the usual way with acetone and ethanolic $\mathrm{KOH}$ at $15^{\circ}$. Dilutions were carried out after varying periods of time. The results (Table 2) show that the optical density reaches a maximum within $5 \mathrm{~min}$. and falls off very slowly.

Table 2. Effect of time of reaction on optical density of purple colour given by 3:5-dinitrobenzoates at $15^{\circ}$ in ethanolic $\mathrm{KOH}$

\begin{tabular}{|c|c|c|c|c|}
\hline \multirow{3}{*}{$\begin{array}{l}\text { Time to } \\
\text { dilution } \\
\text { (min.) }\end{array}$} & \multicolumn{4}{|c|}{ Optical density $(E)$} \\
\hline & \multirow{2}{*}{$\begin{array}{c}\text { Cholesterol } \\
\text { ester } \\
\text { (0.2 mg.) }\end{array}$} & \multirow{2}{*}{$\begin{array}{c}\text { Pregnanediol } \\
\text { ester } \\
(0 \cdot 2 \mathrm{mg} .)\end{array}$} & \multicolumn{2}{|c|}{$\begin{array}{c}\text { Urinary } \\
\text { non-ketonic } \\
\text { alcohol esters } \\
(0.2 \mathrm{mg} .)\end{array}$} \\
\hline & & & I & II \\
\hline 2 & 0.383 & 0.628 & 0.436 & 0.485 \\
\hline 3 & 0.386 & 0.622 & 0.442 & 0.490 \\
\hline 4 & 0.388 & 0.624 & 0.447 & 0.489 \\
\hline 5 & $0 \cdot 387$ & 0.610 & 0.443 & 0.495 \\
\hline 6 & 0.392 & 0.618 & 0.434 & 0.493 \\
\hline 7 & $0 \cdot 386$ & 0.621 & 0.432 & 0.496 \\
\hline 8 & $0 \cdot 384$ & 0.621 & 0.444 & 0.494 \\
\hline 10 & 0.387 & $0 \cdot 630$ & 0.422 & 0.495 \\
\hline 15 & 0.373 & 0.605 & 0.430 & 0.492 \\
\hline
\end{tabular}

Concentration of $\mathrm{KOH}$. Variation of the volume of ethanolic $\mathrm{KOH}$ added $(0.05-0.4 \mathrm{ml}$. of $0.1 \% \mathrm{KOH})$ was without significant effect upon colour development in the case of cholesterol and pregnanediol esters (Table 3). With two different batches of mixed esters from human urine, $0.2 \mathrm{ml}$. of $0.1 \% \mathrm{KOH}$ was the minimum volume for maximum optical density.
Stability of colour. When ethanol was used as the diluting solvent the optical density decreased slowly (approx. $0.5 \% /$ min.). After dilution with acetone, however, the optical density remained constant for some hours without change of colour.

Esterification blank. The conditions given for esterifying non-ketonic alcohols were determined by using cholesterol and pregnanediol as representative steroid alcohols. Weight of the product and optical density in the colour reaction (based upon the dinitrophenyl radical) were used as criteria of completeness of reaction. During preliminary work, both the weight and optical density of the product were considerably higher than expected. At first this was thought to be due to incomplete removal of 3:5-dinitrobenzoic acid, but it was clear from control experiments that this was not the case.

A blank experiment carried out on the reagents, in the absence of the alcohol, left a small crystalline residue which gave the colour reaction typical of an ester.

Table 4. Effect of volume of pyridine and time of reaction on the optical density of the 'blank' during esterification

(3:5-Dinitrobenzoyl chloride (50 mg.) in each experiment.)

$\begin{gathered}\text { Volume of } \\ \text { pyridine } \\ \text { (ml.) }\end{gathered}$
$0 \cdot 1$
0.2
0.5
$0 \cdot 1$
$0 \cdot 1$
$0 \cdot 1$
0.1
reaction 30 sec. 30 sec. 30 sec. 30 sec. $10 \mathrm{~min}$ $20 \mathrm{~min}$. $30 \mathrm{~min}$.
Time of
Calculated optical density $(E \times d)$ of 'blank'*
$1 \cdot 1$
$1 \cdot 6$
$2 \cdot 1$
$1 \cdot 1$
$1 \cdot 3$
$1 \cdot 6$
$2 \cdot 2$

* For definition of $E \times d$ see text, page 579 .

Rigid purification of the reagents (the pyridine by forming the zinc chloride complex (Vogel, 1948), and the acid chloride by repeated recrystallization) failed materially to reduce this artifact. The possibility of compound formation between 3:5-dinitrobenzoyl chloride and pyridine was considered, and attempts were made to minimize this potential source of contamination. Table 4 shows the effect of variation of the volume of pyridine and the influence of time of reaction upon the optical density blank produced by the reagents alone.

A ratio of 1:5 (w/w) between alcohol and acid chloride has been adopted arbitrarily as standard, although at least

Table 3. Effect of concentrations of $\mathrm{KOH}$ on optical density of ethanolic solutions of 3:5-dinitrobenzoates

\begin{tabular}{|c|c|c|c|c|c|}
\hline \multirow{3}{*}{$\begin{array}{c}\text { Ethanolic } \\
\text { KOH } \\
\text { (ml. of } 0 \cdot 1 \% \text { ) }\end{array}$} & \multirow{3}{*}{$\underset{(\mu \text { moles })}{\mathbf{K O H}}$} & \multicolumn{4}{|c|}{ Optical density $(E)$} \\
\hline & & \multirow{2}{*}{$\begin{array}{c}\text { Cholesterol } \\
\text { ester } \\
(0.243 \mathrm{mg} ., \\
0.42 \mu \mathrm{mole})\end{array}$} & \multirow{2}{*}{$\begin{array}{c}\text { Pregnanediol } \\
\text { ester } \\
(0.20 \mathrm{mg} ., \\
0 \cdot 28 \mu \mathrm{mole})\end{array}$} & \multicolumn{2}{|c|}{$\begin{array}{l}\text { Urinary non-ketonic } \\
\text { alcohol esters } \\
(0 \cdot 20 \mathrm{mg} .)\end{array}$} \\
\hline & & & & I & II \\
\hline $\begin{array}{l}0 \cdot 05 \\
0 \cdot 10 \\
0 \cdot 20 \\
0 \cdot 30 \\
0 \cdot 40\end{array}$ & $\begin{array}{l}0.9 \\
1.8 \\
3.6 \\
5 \cdot 4 \\
7.2\end{array}$ & $\begin{array}{l}0.455 \\
0.458 \\
0.458 \\
0.459 \\
0.454\end{array}$ & $\begin{array}{l}0 \cdot 547 \\
0 \cdot 603 \\
0 \cdot 631 \\
0 \cdot 614 \\
0 \cdot 611\end{array}$ & $\begin{array}{l}0 \cdot 134 \\
0 \cdot 424 \\
0 \cdot 434 \\
0 \cdot 421 \\
0.428\end{array}$ & $\begin{array}{l}0.476 \\
0.470 \\
0.478 \\
0.473 \\
0.470\end{array}$ \\
\hline
\end{tabular}


in the case of cholesterol the esterification appears complete when the ratio is $1: 3$ (Table 5).

It will be seen from this table that it has not been possible completely to remove the blank (approx. $3 \%$ of the total optical density), but it is felt that the conditions of reaction reduce it to a minimum consistent with complete esterification. Furthermore, as this blank is apparently dependent upon the volume of pyridine used, provided always that sufficient pyridine is present, the percentage contamination of any material esterified will depend upon the number of hydroxyl groups available. Thus the weight and optical density of the ester of a polyhydroxy compound will be greater and the blank contamination relatively less.

\section{Table 5. Effect of variation of alcohol/3:5-dinitro-} benzoyl chloride ratio on degree of esterification

(Measured by optical density using $10 \mathrm{mg}$. cholesterol in each experiment.)

$\begin{array}{cccc}\begin{array}{c}\text { 3:5-Dinitro- } \\ \text { benzoyl chloride }\end{array} & \begin{array}{c}\text { Weight of } \\ \text { ester (mg.) } \\ \text { (mg.) }\end{array} & \overbrace{}^{\text {(theor. 15.0 mg.) }} \begin{array}{cc}\text { 'Blank' } \\ \text { densities }(E \times d)\end{array} & \begin{array}{c}\text { Ester + } \\ \text { 'blank' }\end{array} \\ 30 & 14 \cdot 4 & 1 \cdot 10 & 28 \cdot 0 \\ 40 & 14.9 & 1 \cdot 10 & 28 \cdot 8 \\ 50 & 15 \cdot 1 & 1.04 & 28 \cdot 0 \\ 100 & 15 \cdot 3 & 1 \cdot 70 & 28 \cdot 8 .\end{array}$

* For definition of $E \times d$ see text, p. 579 .

Esterification of pure alcohols. Using the above method a number of alcohols both ketonic and non-ketonic have been esterified. Table 6 shows a comparison of weight and optical density of these esters as determined on the product prior to recrystallization.

Upon the basis of weight of ester obtained and comparison of optical density with that of esters obtained from pure compounds, it appears that esterification is substantially complete in every case. In this respect the method compares favourably with that of Engel et al. (1950); these workers, using 3:5-dinitrophthalic anhydride as the esterifying agent, obtained yields of ester based upon pure cholesterol hemi3:5-dinitrophthalate ranging from 51 to $93 \%$.

\section{Properties of pure dinitrobenzoates}

The following dinitrobenzoates have been obtained in a crystalline form; melting points are uncorrected; specific rotations are in $\mathrm{CHCl}_{3}(c, 1 \cdot 0)$ at 20-25. Monodinitrobenzoates: Androsterone (androstan-3 $\alpha$-ol-17-one), m.p. 181$182^{\circ}$. (Found: $\mathrm{C}, 64 \cdot 5 ; \mathrm{H}, 6 \cdot 3 . \mathrm{C}_{28} \mathrm{H}_{32} \mathrm{O}_{2} \mathrm{~N}_{2}$ requires $\mathrm{C}, 64 \cdot 5$; H, 6.6.) Androstan-3 $\beta$-ol-17-one, m.p. 235-236. (Found: $\mathrm{C}, 64 \cdot 2 ; \mathrm{H}, 6 \cdot 7 . \mathrm{C}_{26} \mathrm{H}_{32} \mathrm{O}_{7} \mathrm{~N}_{2}$ requires $\mathrm{C}, 64 \cdot 5 ; \mathrm{H}, 6 \cdot 6$.) Androst-5-en-3 $\beta$-ol-17-one, m.p. 221-222 ${ }^{\circ}$ (Found: C, 64.2; $\mathrm{H}, 6 \cdot 1 ; \mathrm{N}, 5 \cdot 7 . \mathrm{C}_{26} \mathrm{H}_{30} \mathrm{O}_{7} \mathrm{~N}_{2}$ requires $\mathrm{C}, 64 \cdot 7 ; \mathrm{H}, 6 \cdot 2 ; \mathrm{N}, 5 \cdot 8$.) Di-dinitrobenzoates: Pregnane-3 $\alpha: 20 \alpha$-diol, m.p. 245-246 ${ }^{\circ}$; $[\alpha]_{D}+14 \cdot 5^{\circ}$. (Found: $\mathrm{C}, 59 \cdot 5 ; \mathrm{H}, 5 \cdot 6 . \mathrm{C}_{35} \mathrm{H}_{40} \mathrm{O}_{12} \mathrm{~N}_{4}$ requires C, 59.4; H, 5.6.) 5 $\alpha$-Pregnane-3 $\alpha: 20 \alpha-$ diol, m.p. 200-201 ${ }^{\circ}$; $[\alpha]_{D}+6 \cdot 5^{\circ}$. (Found: $\mathrm{C}, 59 \cdot 9 ; \mathrm{H}, 5 \cdot 7 ; \mathrm{C}_{35} \mathrm{H}_{40} \mathrm{O}_{12} \mathrm{~N}_{4}$ requires C, $59 \cdot 4 ; \mathrm{H}, 5 \cdot 6$.)

\section{DISCUSSION}

The above method has been in use for some months, in estimating pure steroid esters, and in following the elution of mixed esters from adsorption chromatograms.

The sensitivity of the method is of the same order as that of the Zimmermann reaction and the method can be applied without any prolonged incubation period, using an extremely dilute ethanolic potassium hydroxide solution. It compares favourably in sensitivity with the method described by Engel et al. (1950) for dinitrophthalates; thus cholesterol 3:5dinitrobenzoate in the present method gives an optical density of $1 \cdot 08 / \mu$ mole as compared with $0.5 / \mu$ mole of cholesterol hemidinitrophthalate in the earlier method. The choice of volume for diluting the reaction mixture after development of colour is an arbitrary one, and with suitable microcells the method can be used to estimate very small amounts of ester in solution. Preliminary experiments have shown that the esters can be readily located on paper chromatograms by spraying with

\section{Table 6. Esterification of steroid alcohols with 3:5-dinitrobenzoyl chloride}

(10 mg. alcohol esterified.)

\begin{tabular}{|c|c|c|c|}
\hline \multirow[b]{2}{*}{ Compound esterified } & \multirow[b]{2}{*}{$\begin{array}{c}\text { *Optical } \\
\text { density } / \mu \text { mole }\end{array}$} & \multicolumn{2}{|c|}{ Weight of ester } \\
\hline & & $\begin{array}{l}\text { Found } \\
\text { (mg.) }\end{array}$ & $\begin{array}{l}\text { Calculated } \\
\text { (mg.) }\end{array}$ \\
\hline 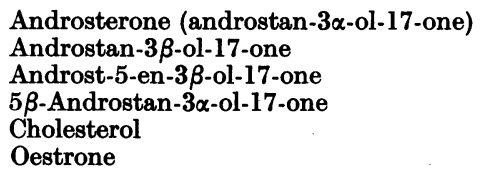 & $\begin{array}{l}1 \cdot 15 \\
1 \cdot 17 \\
1 \cdot 15 \\
1 \cdot 17 \\
1 \cdot 08 \\
1 \cdot 22\end{array}$ & $\begin{array}{l}18 \cdot 5 \\
16 \cdot 9 \\
16 \cdot 6 \\
19 \cdot 4 \\
15 \cdot 0 \\
17 \cdot 9\end{array}$ & $\begin{array}{l}16 \cdot 7 \\
16 \cdot 7 \\
16 \cdot 8 \\
16 \cdot 7 \\
15 \cdot 0 \\
17 \cdot 2\end{array}$ \\
\hline $\begin{array}{l}\text { Pregnane-3 } \alpha: 20 \alpha \text {-diol } \\
5 \alpha \text {-Pregnane-3 } \alpha: 20 \alpha \text {-diol } \\
\text { Androstane-3 } \alpha: 17 \beta \text {-diol } \\
\text { Androst-5-ene-3 } \beta \text { :17 } \beta \text {-diol } \\
\text { Oestradiol-17 } \beta\end{array}$ & $\begin{array}{l}2 \cdot 27 \\
2 \cdot 39 \\
2 \cdot 10 \\
2 \cdot 00 \\
2 \cdot 18\end{array}$ & $\begin{array}{l}23 \cdot 8 \\
25 \cdot 1 \\
26 \cdot 5 \\
23 \cdot 7 \\
25 \cdot 4\end{array}$ & $\begin{array}{l}22 \cdot 2 \\
22 \cdot 2 \\
23 \cdot 3 \\
23 \cdot 4 \\
24 \cdot 4\end{array}$ \\
\hline $\begin{array}{l}\text { Pregnane-3 } \alpha: 12 \alpha: 20 \text {-triol } \\
5 \alpha \text {-Pregnane-3 } \beta: 16 \alpha: 20 \beta \text {-triol }\end{array}$ & $\begin{array}{l}3 \cdot 28 \\
3 \cdot 39\end{array}$ & $\begin{array}{l}30 \cdot 2 \\
30 \cdot 8\end{array}$ & $\begin{array}{l}27 \cdot 6 \\
27 \cdot 6\end{array}$ \\
\hline
\end{tabular}

* Optical density $/ \mu$ mole $=E \times d \times \frac{\text { mol.wt. alcohol }}{\text { wt. esterified }} \times 10^{-6} . E \times d$ is defined on p. 579 . 
a mixture of equal volumes of acetone and $0.1 \%$ potassium hydroxide in ethanol.

The linear relationship between optical density and weight in the compounds studied, together with the stoicheiometric behaviour of the dinitrobenzoyl radical in the polyhydroxy esters, render this colour reaction particularly useful for the investigation of both ketonic and non-ketonic alcohol fractions of urinary steroids.

The ease and completeness with which all the steroid alcohols tested have been esterified, suggests that the method may be applicable to a wide range of compounds. Mono-, di- and tri-hydroxy compounds were all fully esterified in contrast to the results obtained by Engel et al. (1950), using 3:5-dinitrophthalic anhydride, when the yield varied from 51-93\% of the theoretical. The artifact introduced by the blank has been reduced to $1-3 \%$ of the total and is not a serious disadvantage.

\section{SUMMARY}

1. Conditions have been described for the preparation of 3:5-dinitrobenzoates of steroid alcohols and of urinary non-ketonic alcohol fractions.

2. The 3:5-dinitrobenzoates of steroid alcohols dissolve in acetone and give a stable purple colour when dilute ethanolic potassium hydroxide is added.

3. The conditions for the development of maximum optical density have been studied.

4. All of the esters so far studied obey Beer's law in the range $0.1-0.5 \mathrm{mg}$. of ester.

5. The optical density is proportional to the amount of dinitrobenzoyl radical in esters of monoand poly-hydroxy compounds.

We wish to thank Dr V. Petrow and colleagues, Messrs British Drug Houses Ltd., for the gift of some of the steroids used in this work. This investigation forms part of a programme supported by a grant to the Medical School from the British Empire Cancer Campaign.

\title{
REFERENCES
}

Brooks, R. V., Klyne, W. \& Miller, E. (1951). Biochem. $J$. 49, lxxii.

Dobriner, K., Lieberman, S. \& Rhoads, C. P. (1948), J. biol. Chem. 172, 241.

Engel, L. L., Patterson, H. R., Wilson, H. \& Schinkel, M. (1950). J. biol. Chem. 183, 47.

Jones, R. N. \& Dobriner, K. (1949). Vitam. \& Horm. 7, 293.
Pincus, G. (1943). Endocrinology, 32, 176

Pincus, G. (1948). Recent Progr. Hormone Res. 3, 123.

Tompsett, S. L. \& Oastler, E. G. (1948). Glasg. med. J. 29 , 133.

Vogel, A. I. (1948). Practical Organic Chemistry. London: Longmans Green \& Co.

\section{Urinary Steroids}

\section{CHROMATOGRAPHY OF 3:5-DINITROBENZOATES: APPLICATION TO THE NON-KETONIC ALCOHOL FRACTION}

\author{
By A. E. KELliE ANd A. P. WADE \\ Courtauld Institute of Biochemistry, Middlesex Hospital Medical School, London, W. 1
}

(Received 26 May 1952)

The non-ketonic alcohol fraction constitutes a substantial portion of the total neutral fraction of human urine. Although its weight may be equal to, or greater than, that of the ketonic alcohol fraction, it has been much less extensively studied. One of the main reasons has been the absence of any reaction characteristic of the components of this group which could be used qualitatively and quantitatively as the Zimmermann reaction has been used in following and purifying ketonic material.

The non-ketonic alcohol fraction includes pregnane-3 $\alpha: 20 \alpha$-diol, one of the first steroids to be isolated from pregnancy urine (Marrian, 1929). Quantitative methods of estimation (see Haslewood, 1950) reveal that pregnanediol is excreted by the normal non-pregnant woman only during the luteal phase of the menstrual cycle, and in traces by normal males. This compound apart, knowledge of the composition of the non-ketonic alcohol fraction rests almost exclusively upon isolations from pathological urines. Mason \& Kepler (1945) isolated pregnane-3 $\alpha: 17 \alpha: 20 \alpha$-triol, and androst-5-ene-3 $\beta$ : $17 \beta$-diol from the urine of patients with adrenocortical hyperplasia and adrenocortical tumour respectively. Mason (1948) has reported the isolation of pregnane-3 $\alpha: 20 \alpha$-diol-11-one from the urine of two patients with Addison's disease who were given large amounts of 11-dehydrocorticosterone and its acetate. (The 11-oxygen function is unreactive and this compound appeared in the non-ketonic 